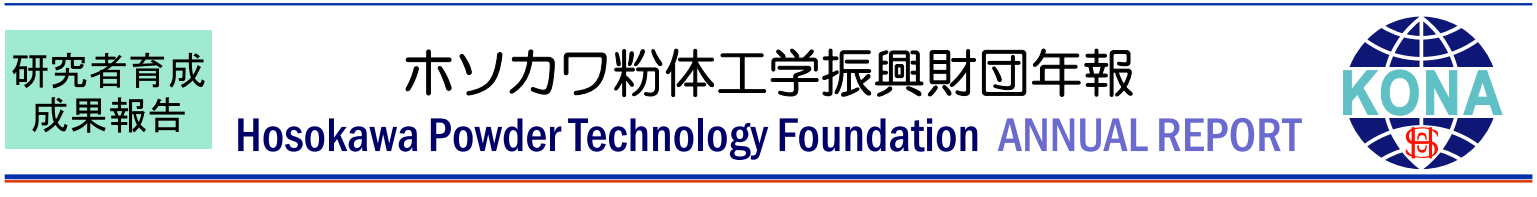

\title{
微粒子の構造化と光触媒材料への応用に関する研究 \\ Study on Nanostructurization Material and its Application for Photocatalytic
}

\author{
13503 \\ 援助対象者 Scholarship Student: Osi ARUTANTI \\ 広島大学大学院工学研究科化学工学専攻 博士後期課程 3 年 \\ Department chemical engineering, Hiroshima University, PhD Student (D3) \\ 研究指導者 Academic Leader：奥山 喜久夫 Kikuo OKUYAMA \\ 広島大学大学院工学研究科化学工学専攻 教授 \\ Department chemical engineering, Hiroshima University, Professor
}

\section{成 果 の 概 要}

Titanium dioxide $\left(\mathrm{TiO}_{2}\right)$ is one of the prospective catalysts because it possesses excellence properties (e.g., chemical and thermal stability, harmless, and inexpensive). With these advantages, the production of photocatalyst material with low cost production will be achieved. However, pure $\mathrm{TiO}_{2}$ is only can be activated under UV light. Therefore, preparation of $\mathrm{TiO}_{2}$ with high photocatalytic performance is inevitable. Extensive efforts have been devoted to solve the above problem. One of the methods is by combining $\mathrm{TiO}_{2}$ with other material semiconductor. As an alternative of photocatalyst, tungsten trioxide $\left(\mathrm{WO}_{3}\right)$ has been proposed as a good candidate. $\mathrm{WO}_{3}$ has been widely studied because an excellent prospective material for a wide range of applications due to its affinity for visible light. Therefore, combination of $\mathrm{TiO}_{2}$ and $\mathrm{WO}_{3}$ becoming an interesting subject in the photocatalytic field.

Here we reported the synthesis of composite
$\mathrm{WO}_{3} / \mathrm{TiO}_{2}$ Nanoparticles using a flame spraypyrolysis method. ${ }^{[1]}$ Ammonium metatungstate (AMT) and titanium isopropoxide (TTIP) were used as a $\mathrm{WO}_{3}$ source and $\mathrm{TiO}_{2}$ source, respectively. The mass ratio of AMT/TTIP was varied: 0/100; 10/90; $25 / 75$; and $100 / 0$. The effect of mass ratio on the particles morphology and photocatalytic activity is shown in Fig. 1. The results showed that the particle size decreased (from 89 to $24 \mathrm{~nm}$ ) by increasing AMT amount. We also found that the increases in the AMT amount influenced the decreases in band gap energy, and increases in photocatalytic activity. Below than $25 \mathrm{wt} \%$ of AMT, the change of photocatalytic activity is mainly influenced by band gap energy. However, the surface area also plays important role in the change of photocatalytic activity.

Based on the previous research, the next subject we focused on the optimization of $\mathrm{WO}_{3}$ material for photocatalytic application. Many researches about this material have been reported, especially the use 


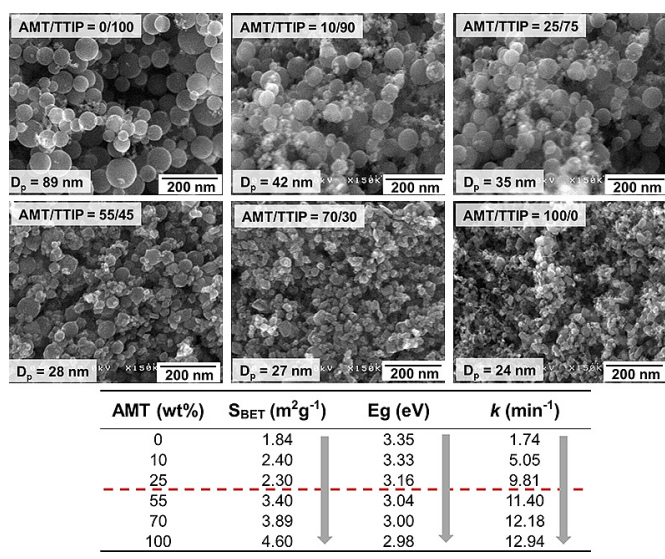

Fig. 1 The effect of AMT amount on the physical and chemical properties of the prepared particles.

of $\mathrm{WO}_{3}$ nanoparticles for catalyst material. The use of nanoparticles is effective to improve photocatalytic performance. However, the special treatment regarding to the reuse or removal after photocatalytic process is needed. Therefore, design material in larger size with good performance is important.

Here, nanostructurization of $\mathrm{WO}_{3}$ nanoparticles with controllable porous structure using spray drying method has been successfully. ${ }^{[2]} \mathrm{WO}_{3}$ nanoparticles $(7 \mathrm{~nm})$ and Polystyrene (PS) sphere $(250 \mathrm{~nm})$ were used as $\mathrm{WO}_{3}$ source and template, respectively. To control the porous structure, mass ratio of $\mathrm{PS} / \mathrm{WO}_{3}$ was varied from 0.00 to 0.40 . $\mathrm{Pt}$ was added as co-catalyst material. The effect of mass ratio of $\mathrm{PS} / \mathrm{WO}_{3}$ on the particle morphology and photocatalytic activity is shown in Fig. 2. We also analyzed $\mathrm{WO}_{3}$ particles prepared from ammonium tungstate pentahydrate (ATP). The results showed that the number porous structure increased by increasing PS ratio. 0.32 was the optimum mass ratio to produce particles with highly ordered macroporous structure. The broken particles

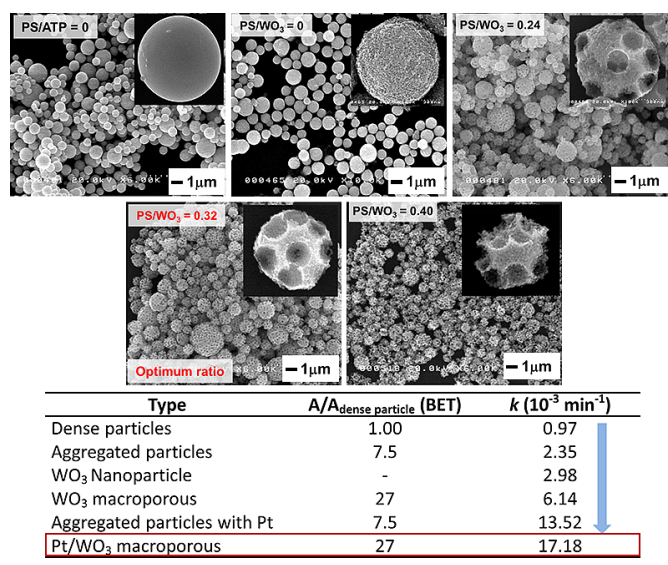

Fig. 2 The effect of $\mathrm{PS} / \mathrm{WO}_{3}$ mass ratio on the particles morphology and photocatalytic activity.

were produced when the mass ratio was above 0.32 . Photocatalytic activity increased by changing the morphology of particles. $\mathrm{WO}_{3}$ particles from ATP have a lowest performance because of the lowest surface area. Aggregated $\mathrm{WO}_{3}$ particles have a lower performance than $\mathrm{WO}_{3}$ NPs. However, by adding porous structure, photocatalytic activity was higher than $\mathrm{WO}_{3}$ NPs. The presence of Pt NPs considerably improved the photodegradation rate. It can be concluded that the presence of porous structure and Pt NPs is effective to enhance photocatalytic activity.

\section{参考文献}

[1] Arutanti O., Nandiyanto A.B.D., Ogi T., Iskandar F., Kim T.O., Okuyama K.: "Synthesis of composite $\mathrm{WO}_{3}$ / $\mathrm{TiO}_{2}$ nanoparticles by flame-assisted spray pyrolysis and their photocatalytic activity", Journal of Alloys and Compounds, 591 (2014) 121-126.

[2] Arutanti O., Nandiyanto A.B.D., Ogi T., Kim T.O., Okuyama K.: "Influences of porous structurization and Pt addition on the improvement of photocatalytic performance of $\mathrm{WO}_{3}$ particles", ACS Applied Materials \& Interfaces, 7 (2015) 3009-3017. 


\section{外部発表成果}

\section{論文発表}

1. Arutanti, O., Nandiyanto A. B. D., Ogi T., Iskandar F., Kim T. O., Okuyama K.: "Synthesis of composite $\mathrm{WO}_{3} / \mathrm{TiO}_{2}$ nanoparticles by flame-assisted spray pyrolysis and their photocatalytic activity", Journal of Alloys and Compounds, 591 (2014) 121-126.

2. Arutanti, O., Nandiyanto A. B. D., Ogi T., Kim T. O., Okuyama K.: "Influences of porous structurization and $\mathrm{Pt}$ addition on the improvement of photocatalytic performance of $\mathrm{WO}_{3}$ particles", ACS Applied Materials \& Interfaces, 7 (2015) 3009-3017.

\section{口頭・ポスター発表}

1. Arutanti Osi, Ogi Takashi, Nandiyanto Asep Bayu Dani, Okuyama Kikuo: "Synthesis of $\mathrm{WO}_{3}$ Particles with Controllable Crystallite and Particle Sizes Using A Spray-Pyrolysis Method and Their Photocatalytic Performance", PP09007, 2014 International Aerosol Conference, Busan, Korea (Aug. 28-Sep. 2, 2014). 